\title{
Attitudes towards cancer predictive testing and transmission of information to the family
}

\author{
C Julian-Reynier, F Eisinger, P Vennin, F Chabal, Y Aurran, C Noguès, Y-J Bignon, M \\ Machelard-Roumagnac, C Maugard-Louboutin, D Serin, B Blanc, P Orsoni, H Sobol
}

\section{INSERM U379, "Epidémiologie et Sciences Sociales appliquées à l'Innovation Médicale", Centre Régional de Lutte contre le Cancer, 232 Boulevard Sainte Marguerite, 13273 Marseille cedex 9, France \\ C Julian-Reynier \\ $F$ Eisinger \\ F Chabal \\ Y Aurran \\ H Sobol \\ Institut \\ Paoli-Calmettes, \\ Marseille, France \\ F Eisinger \\ H Sobol}

Centre Oscar

Lambret, Lille, France

$P$ Vennin

Centre René

Huguenin, St Cloud,

France

$C$ Noguès

Centre Jean

Perrin-INSERM

CRI9402,

Clermont-Ferrand,

France

Y-J Bignon

Centre Claudius

Regaud, Toulouse,

France

M Machelard-Roumagnac

Centre René

Gauducheau, Nantes,

France

C Maugard-Louboutin

Clinique

Sainte-Catherine,

Avignon, France

D Serin

Hôpital de la

Conception, Marseille, France

B Blanc

Hôpital Nord, Marseille, France P Orsoni

Correspondence to: Dr Julian-Reynier.

Received 3 January 1996 Revised version accepted for publication 24 April 1996

\begin{abstract}
Before the organisation of breast cancer predictive testing in France, consultands' attitudes towards this kind of testing and towards passing on information about the family cancer risk to their relatives were investigated. This survey was carried out from January 1994 to January 1995 at six specialised cancer genetic clinics located in different parts of France. Female consultands who were first degree relatives of cancer patients and who had at least one case of breast cancer in their family, affecting either themselves or a first degree relative or both, participated in this study. Among the 248 eligible consultands attending the clinics during the study period, $84.3 \%$ answered a postconsultation questionnaire. Among the 209 respondents, $40.7 \%(n=85)$ were cancer patients and $59.3 \% \quad(n=124)$ were healthy consultands. A high consensus in favour of genetic testing was noted, since $87.7 \%$ of the sample stated that they would ask for breast cancer gene testing if this test became available. The underlying assumption of $96.6 \%$ of the women was that their health surveillance would be improved after a positive test. A high awareness of the anxiety that would be generated in a family after a positive result was observed and found to be associated $(p<0.05)$ with the anxiety and depressive profiles of the patients. Half of the healthy respondents said they would not change their attitude towards screening if the results of predictive testing turned out to be negative. Only $13.7 \%$ of the 161 patients who stated that the oncogeneticists asked them to contact their relatives firmly refused to do so, mainly because of difficult family relationships. (F Med Genet 1996;33:731-736)
\end{abstract}

Key words: breast cancer; clinical genetics; predictive testing; social epidemiology.

Public opinion seems to be quite in favour of genetic testing, especially in the field of breast and colon cancer predictive testing, as established in some recent North American surveys. ${ }^{1-4}$ The two genes identified in hereditary breast cancer (BRCA1, BRCA2) can now be studied by performing mutation analysis. These genes are likely to be responsible for the majority of all the hereditary cases, ${ }^{5-9}$ but it is possible that a third gene may exist. ${ }^{10}$ One of the main advantages of knowing patients' attitudes a priori towards cancer predictive testing is that this information can help us to predict the demand, expectations, and previous beliefs of the public and the perceived usefulness of testing. The attitudes of "at risk" patients towards Huntington's disease, which used to be cited as the only existing model for cancer predictive testing, is now known to be a poor model for cancer predictive testing. ${ }^{11-13}$ Our aim was to document the attitudes towards breast cancer predictive testing of women with a first degree relative with cancer and towards the transmission of information about the cancer risk to their relatives. This study was carried out at six cancer genetic clinics located in various French cities.

\section{Material and methods}

POPULATION SAMPLE

The six participating regional cancer centres were selected with a view to giving a representative picture of the French population as a whole (south: Marseille, Toulouse; north: Lille; west: Nantes; centre: Paris/St Cloud, Clermont-Ferrand) and covered a total population of more than 4 million inhabitants. The main criterion used for inclusion in the study was the presence of breast cancer running in the family, either in the patient or in at least one first degree relative when she was not affected herself. All the healthy cases included had at least one first degree relative with breast cancer. All the affected ones had a first degree relative with cancer and when the consultand herself was not affected she had at least one first degree relative who was. The consultands were female adult cancer patients and healthy patients who were asked to participate when attending the cancer genetic clinics for the first time between January 1994 and January 1995.

\section{CONSULTANDS' QUESTIONNAIRES}

The consultands were mailed a standardised questionnaire (with a stamped envelope) during the week after the consultation. If no answer was received within two weeks of the first letter, a reminder was sent, followed after a second period of two weeks by a complete package (letter, questionnaire, and stamped envelope). The questions asked about the attitudes towards breast cancer predictive testing are given in the appendix.

Both open ended and closed questions were used to enquire about the transmission of information to relatives about the family cancer risk, how this information was received, 
Table $1 A$ Descriptive characteristics of the cancer and healthy groups $(n=209)$

\begin{tabular}{|c|c|c|c|c|c|c|c|}
\hline & \multicolumn{2}{|c|}{$\begin{array}{l}\text { Cancer patients } \\
(n=85)\end{array}$} & \multicolumn{2}{|c|}{$\begin{array}{l}\text { Healthy patients } \\
(n=124)\end{array}$} & \multicolumn{3}{|c|}{$\begin{array}{l}\text { Total } \\
(n=209)\end{array}$} \\
\hline & No & $\%$ & No & $\%$ & No & $\%$ & $p$ \\
\hline Educational level & & & & & & & NS \\
\hline$\leqslant$ High school & 54 & 63.5 & 74 & 59.7 & 128 & 61.2 & \\
\hline$>$ High school & 31 & 36.5 & 50 & 40.3 & 81 & 38.8 & \\
\hline Children & & & & & & & $<0.01$ \\
\hline Yes & 80 & 94.1 & 100 & 80.6 & 180 & 86.1 & \\
\hline No & 5 & 5.9 & 24 & 19.4 & 29 & 13.9 & \\
\hline Genetic risk in the family (oncogeneticist) & & & & & & & $<0.01$ \\
\hline Likely & 75 & 88.2 & 88 & 71.0 & 163 & 78.0 & \\
\hline Unlikely & 7 & 8.2 & 22 & 17.7 & 29 & 13.9 & \\
\hline Undetermined & 3 & 3.5 & 14 & 11.3 & 17 & 8.1 & \\
\hline $\begin{array}{l}\text { Existence of an increased cancer risk for the } \\
\text { family (consultand's opinion) }\end{array}$ & & & & & & & NS \\
\hline Yes & 64 & 75.3 & 80 & 64.5 & 144 & 68.9 & \\
\hline No & 7 & 8.2 & 20 & 16.1 & 27 & 12.9 & \\
\hline Don't know & 14 & 16.5 & 24 & 19.4 & 38 & 18.2 & \\
\hline
\end{tabular}

Table 1B Age and psychological characteristics: anxiety (STAI) and depression (CES-D)

\begin{tabular}{lllll}
\hline & Cancer patients $(n=85)$ & Healthy patients $(n=124)$ & $\begin{array}{l}\text { Total } \\
(n=209)\end{array}$ & \\
\cline { 2 - 4 } & Mean $(S D)$ & Mean $(S D)$ & Mean $(S D)$ & $<$ \\
\hline Age & $53.4(10.8)$ & $44.2(12.0)$ & $47.8(11.9)$ & NS \\
STAI state & $34.5(9.3)$ & $35.0(10.4)$ & $34.8(9.9)$ & 0.06 \\
STAI trait & $46.5(10.4)$ & $43.6(10.2)$ & $44.8(10.4)$ & $<0.01$ \\
CES-D & $18.8(9.6)$ & $15.0(10.0)$ & $16.5(10.0)$ & \\
\hline
\end{tabular}

Table 2 Attitudes towards predictive testing for breast cancer ( $n=209)$

\begin{tabular}{|c|c|c|c|c|c|c|c|}
\hline & \multicolumn{2}{|c|}{ Cancer patients } & \multicolumn{2}{|c|}{ Healthy patient } & \multicolumn{3}{|l|}{ Total } \\
\hline & No & $\%$ & No & $\%$ & No & $\%$ & $p$ \\
\hline Would you ask for the test? & & & & & & & $<0.01$ \\
\hline Yes & 64 & 76.2 & 115 & 95.8 & 179 & 87.7 & \\
\hline No & 0 & 0.0 & 1 & 0.8 & 1 & 0.5 & \\
\hline Don't know & 20 & 23.8 & 4 & 3.4 & 24 & 11.8 & \\
\hline Total & 84 & 100.0 & 120 & 100.0 & 204 & 100.0 & \\
\hline $\begin{array}{l}\text { Would you inform your relatives } \\
\text { about the availability of the test? }\end{array}$ & & & & & & & NS \\
\hline Yes & 74 & 88.1 & 108 & 90.8 & 182 & 89.6 & \\
\hline No & 0 & 0.0 & 3 & 2.5 & 3 & 1.5 & \\
\hline Don't know & 10 & 11.9 & 8 & 6.7 & 18 & 8.9 & \\
\hline Total & 84 & 100.0 & 119 & 100.0 & 203 & 100.0 & \\
\hline
\end{tabular}

and the reasons for not informing relatives. Detailed sociocultural characteristics (age, sex, level of education, occupation, number of children, religious practice, place of residence) and psychological characteristics, such as anxiety states and traits ${ }^{14}$ and depressive feelings ${ }^{15}$ were also consistently noted. Perception of the cancer risk to relatives was also recorded.

SPECIALISTS' QUESTIONNAIRE

After each consultation, a two page closed item questionnaire was completed by the oncogeneticist about the content of the consultation. It gave details about the consultand's state of health (affected or not by cancer), whether the consultand had any relatives with cancer and, if so, which organs were affected, whether there was a cancer risk running in the family, and whether other members of the family should be informed.

STATISTICAL ANALYSIS

Descriptive statistics and univariate comparisons (chi square test, $t$ test) were carried out with the SAS statistical package. ${ }^{16}$ The analysis was completed separately on healthy consultands and cancer patients; any results that did not differ significantly between the two groups are not presented here in our comparison based on the cancer or non-cancer status of the participants but they are available from the authors on request. The significance level adopted was a type 1 error lower than or equal to 0.05 .

\section{Results}

CHARACTERISTICS OF THE SAMPLE

Among the 248 eligible women who attended the clinics, $209(84.3 \%)$ returned the questionnaire they received after the consultation. The analysis was carried out on the 124 healthy subjects $(59.3 \%)$ and the 85 affected by cancer $(40.7 \%)$ who responded. Among the cancer patients, $89.4 \% \quad(n=76)$ had breast cancer alone, $5.9 \%$ had cancers of the breast and other sites (two bowel , two ovary, one multiple sites), and $4.7 \%(n=4)$ had ovarian cancer alone. The mean age was 47.8 years (SD 11.9) but the mean age of the cancer patients was significantly higher $(\mathrm{p}<0.01) ; 38.8 \%$ of the consultands had completed education at more than high school level (table 1). The oncogeneticists stated that in $78 \%(n=163)$ of all the cases studied, a genetic risk of cancer was likely to run in the families. Among the other consultands, $13.9 \%$ were unlikely to have a 
Table 3 Perceived personal and familial consequences of positive breast cancer predictive testing $(n=209)$

\begin{tabular}{lrr}
\hline & $N o$ & $\%$ \\
\hline Health surveillance will be $(\mathrm{n}=203)$ & & \\
Better than before & 196 & 96.6 \\
The same as before & 7 & 3.4 \\
The anxiety in the whole family would be $(\mathrm{n}=197)$ & 9 & 4.6 \\
None & 73 & 37.1 \\
Low & 100 & 50.7 \\
High & 15 & 7.6 \\
Very high & 122 & 60.4 \\
Will help you to plan for the future $(\mathrm{n}=202)$ & 15 & 7.4 \\
Yes & 65 & 32.2 \\
No & & 34.3 \\
Don't know & 68 & 9.1 \\
Will have drawbacks (n=198) & 18 & 27.3 \\
Yes a few & 54 & 29.3 \\
Yes a lot & 58 & \\
No & & \\
Don't know & & \\
\end{tabular}

genetic risk of cancer $(n=29)$, and in the case of $8.1 \%(n=17)$ the oncogeneticist could not determine whether this risk was present or not. All these characteristics, the perception of the family risk of cancer by the consultand, and the psychological profiles of the patients are listed in table 1 .

ATTITUDES TOWARDS PREDICTIVE TESTING AND PERCEIVED CONSEQUENCES OF TEST RESULTS A high consensus in favour of predictive testing for breast cancer was observed (table 2) and it was also recognised by a very large majority $(96.6 \%)$ that this testing in the case of positive results should help to plan for more efficient health surveillance (table 3 ). However, the cancer patients were significantly $(p<0.001)$ less in favour of predictive testing than the healthy patients, and most of them mentioned that they were uncertain because they already had breast cancer. Most of the women were also aware of the anxiety that would be generated if the outcome of the test was positive; this fact was mentioned by $95.4 \%$ of them and in $58.3 \%$ of them the level of anxiety was expected to be high or very high (table 3 ).

Table 4 Perception of the anxiety impact of breast cancer predictive testing and psychological characteristics of patients (mean (SD))

\begin{tabular}{|c|c|c|c|}
\hline & \multicolumn{2}{|c|}{ The anxiety in the whole family would be } & \multirow[b]{2}{*}{$p$} \\
\hline & High or very high $(n=115)$ & Low or none $(n=82)$ & \\
\hline Anxiety (STAI state) & $36.1(10.1)$ & $32.7(8.8)$ & 0.01 \\
\hline Anxiety (STAI trait) & $46.2(10.6)$ & $43.2(10.1)$ & 0.05 \\
\hline Depression (CES-D) & $17.6(10.5)$ & $14.9(8.9)$ & 0.06 \\
\hline
\end{tabular}

Table 5 Perceived personal and familial consequences of negative cancer predictive testing $(n=209)$

\begin{tabular}{lrr}
\hline & No & $\%$ \\
\hline The person will change his/her health surveillance $(\mathrm{n}=198)$ & & \\
Yes & 46 & 23.2 \\
No & 103 & 52.0 \\
Don't know & 49 & 24.8 \\
The person will plan his/her future better $(\mathrm{n}=198)$ & 64 & 32.3 \\
Yes & 60 & 30.3 \\
No & 74 & 37.4 \\
Don't know & 72 & 37.1 \\
Will have an effect on the whole family $(\mathrm{n}=194)$ & 48 & 24.8 \\
Yes & 74 & 38.1 \\
No & 18 & 9.7 \\
Don't know & 105 & 56.1 \\
Will have drawbacks (n=187) & 64 & 34.2 \\
Yes & & \\
No & & \\
Don't know & & \\
\hline
\end{tabular}

Table 6 Drawbacks mentioned spontaneously in open ended questions about the subjects' attitudes to a positive (11 subjects mentioned two kinds of drawback) or a negative test result $(n=209)$

\begin{tabular}{lr}
\hline & No \\
\hline Drawbacks of a positive test result & \\
Anxiety & 53 \\
Health monitoring & 11 \\
Change in lifestyle & 8 \\
Change in social relationships & 2 \\
Secret & 1 \\
To become diseased & 1 \\
Change in future & 3 \\
No drawback expressed & 141 \\
Drawbacks of a negative test result & 14 \\
Abandoning intensive medical surveillance & 1 \\
Bitter feelings in the event of getting cancer & 194 \\
No drawback expressed & \\
\hline
\end{tabular}

Those mentioning that a high or very high level of anxiety would be induced in the family by a positive outcome $(n=115)$ were significantly more anxious $(p<0.01)$ themselves (anxiety state and traits) and more depressive $(p=0.06)$ at the time of the survey than those answering no anxiety or only a low level of anxiety $(n=82)$. These results are presented in table 4 . In the responses to the open ended questions (table 5), anxiety was also the most frequent spontaneously mentioned drawback of a positive test besides the need which would arise for health monitoring and a change of lifestyle. Some people mentioned that a positive test would turn them into a diseased person, a keeper of secrets, or would change their future or their social relationships. The result of the test was perceived as helping to plan for the future more frequently $(\mathrm{p}<0.05)$ when positive $(60.4 \%)$ than when negative $(32.3 \%)$ (tables 3 and 5). In the event of a negative test, $52 \%$ of the sample stated that this would not change their health surveillance habits. The main drawback of negative testing which was mentioned spontaneously in response to the open ended questions was also the need it would entail to give up intensive medical surveillance (table 6). The attitudes towards predictive testing were not associated with the participants' sociocultural characteristics, nor did they depend on whether or not a genetic risk actually ran in their family either according to the oncogeneticist's assessment or according to their own perception of their family risk.

ATTITUDES TOWARDS TRANSMISSION OF INFORMATION TO RELATIVES

The consultands' attitudes towards informing their relatives of the existence of genetic testing for breast cancer were very positive, since $89.7 \%$ of them answered that they would inform the family members at risk about the availability of predictive testing (table 2). During the consultation, the oncogeneticist told $68.9 \%$ of the consultands $(n=144)$ that it might be worthwhile contacting their relatives because of the cancer risk. When asked after the consultation whether the oncogeneticist had asked them to contact their relatives, $77 \%$ $(n=161)$ of the women answered that this was the case, although 28 of them had not actually been asked by the oncogeneticist to do so; 11 women did not acknowledge the fact that they 
Table 7 How was the information about the family cancer risk received by your relatives? $(n=110)$

\begin{tabular}{lrr}
\hline & $N o$ & $\%$ \\
\hline Well & 94 & 85.5 \\
Badly & 5 & 4.5 \\
Both well and badly & 2 & 1.8 \\
Indifference & 2 & 1.8 \\
Anxiety & 2 & 1.8 \\
Already informed & 2 & 1.8 \\
Don't know & 3 & 2.7 \\
\hline
\end{tabular}

had been asked to inform their relatives. Among the 161 cases who thought they had been asked to inform their relatives, $70.2 \%$ $(n=113)$ did so before answering the questionnaire, $16.1 \%(n=26)$ said they intended to do so, and $13.7 \%(n=22)$ said they did not intend to do so. The main reason given for not informing the relatives was difficult family relationships $(n=8)$. The other reasons given included the lack of perceived usefulness $(n=2)$, the unpleasantness of the message $(n=1)$, the disturbance it would cause $(n=1)$, and the likelihood that the message would be rejected $(n=1)$. The relatives' reactions to the information about the cancer risk was positive in $85.5 \%$ of the subjects (table 7) and less positive in the remaining $14.5 \%$. It was very badly received in $6.3 \%$ of the 110 cases. Among the 161 cases, $15.5 \% \quad(n=25)$ stated that they would have preferred their relatives to be contacted directly by the oncogeneticist.

\section{Discussion}

The a priori attitudes of French women towards breast cancer predictive testing and towards the transmission of genetic risk information to their relatives, which were documented for the first time in our survey, are highly positive.

The results of this study carried out on a sample of the population attending cancer genetic clinics do not apply to all women with at least one first degree relative affected by cancer. Although having a first degree relative with cancer has usually been taken as the main criterion in other psychosocial studies ${ }^{17}$ to define the target population with an increased genetic risk of cancer, other factors should be taken into account, such as the number of relatives affected, the age at diagnosis, and the bilaterality of breast cancer. ${ }^{18-20}$ Here, $78 \%$ of the first degree relatives of a cancer patient were likely to have a genetic risk running in their family, according to the oncogeneticist's assessment, but this risk assessment or the perception of cancer family risk by the consultands actually had no effect on the attitudes studied here. The consultands attending cancer genetic clinics in France were also found to be more highly educated than the general population $^{21}$; socioeconomic status has already been described as an important factor determining attendance at genetic clinics of other kinds. ${ }^{22}$ This factor must certainly operate in the case of the present target population of cancer genetic clinic patients, since genetic information is available through the health care system. This fact may well have led us to overestimate the positive attitudes liable to exist among the general population of women constituting the target population for biological cancer testing. Another factor that may have contributed to overestimating the positive attitudes is that more women in favour of testing may have participated in the survey. Assuming that all the non-respondents were opposed to testing, this would still give more than $80 \%$ of positive attitudes towards breast cancer predictive testing in the healthy group and more than $60 \%$ in the cancer group.

The positive attitudes of the healthy consultands in this study towards breast cancer predictive testing are comparable to those recently observed in some North American surveys. Lerman $\mathrm{et} \mathrm{al}^{17}$ in a telephone survey of 105 female first degree relatives of breast cancer patients reported that $91 \%$ of them said that they would want to be tested for susceptibility to breast cancer, $4 \%$ that they would not, and $5 \%$ were uncertain. In members of inherited breast-ovarian cancer families participating in a genetic linkage study at the National Cancer Institute, ${ }^{23} 79 \%$ of subjects indicated that they would "definitely" want to be tested, and $16 \%$ that they would "probably" want to be tested for mutations in the BRCA1 gene; a similar trend was observed in another US survey. ${ }^{4}$ The wish to inform the family about the availability of testing and the decision to contact relatives about the cancer family risk rated very high in our study. As far as we know, no published data are available about the transmission of genetic information in cancer families, but the results of other studies on this have been less positive. ${ }^{24}$ Breast cancer families are definitely interested in breast cancer genetic testing, particularly in the present context of research, but people's ideas about the usefulness of testing need to be better understood, since they are the main determinants of these attitudes.

From our results, it emerges clearly that the underlying assumption about the usefulness of positive testing is that it will lead to improved medical surveillance, since this was the opinion of $96.6 \%$ of our sample. Other reasons for testing, ${ }^{2}$ such as worrying about their children's risk, should not hide the fact that most women believe that they will benefit from improved preventive strategies if the result of testing is positive. Given that no strategies have effectively proved to prevent breast cancer so far, or increase the chances of survival, ${ }^{25}$ and that prophylactic bilateral mastectomy is now being frequently advocated as a possible answer to positive breast cancer testing, ${ }^{26}$ since some authors even feel that it constitutes "the only clinically available method of breast cancer prevention", ${ }^{27}$ it has become the duty of cancer geneticists to inform their patients about the state of medical knowledge and about all the uncertainties at stake in cancer genetic screening which "add up to a genetic counselling nightmare". ${ }^{12}$

The wish not to change their health surveillance habits if the outcome of genetic testing was negative was expressed by $52 \%$ of the respondents. Convergent results about the patients' reluctance to abandon intensive 
medical follow up carried out for several years were also obtained in a qualitative survey on familial adenomatous polyposis patients. ${ }^{28}$ This reflects the reassuring effects of long term preventive monitoring in the family context even when it has become unnecessary, but it is also true that a negative result decreases the cumulative risk of breast cancer without cancelling it, since the risk will still be that to which the population as a whole is exposed. ${ }^{29}$

Huntington's disease is often used as a model for cancer predictive testing, but the main difference from breast cancer predictive testing is that there is still no hope of prevention or cure for Huntington's disease. Since the hope of preventing breast cancer is the rationale underlying the existence of cancer genetic clinics, it seems impossible for physicians not to act in some way. In the case of Huntington's disease, the patients' uptake of predictive testing ${ }^{30-32}$ was far lower than expected on the basis of the a priori attitudes towards testing. ${ }^{33-35}$ In the field of hereditary breast cancer, preliminary results indicate that the uptake of testing is close to $50 \% .^{36-37}$ The way in which information about the efficacy of preventive strategies is presented in the future will be one of the keys to ensuring that cancer genetic testing becomes widely accepted.

We thank Dr Gauthier and Dr Bouchard, Mrs Glangeaud, and Professor Spielberger for their authorisation and help in using the STAI Scale on this French population.

1 Hietala M, Hakonen A, Aro A, Niemela P, Peltonen L, Aula $P$. Attitudes toward genetic testing among the general population and relatives of patients with a severe genetic disease : a survey from Finland. Am $\mathcal{F}$ Hum Genet 1995;56:1493-500.

2 Lerman C, Daly M, Masny A, Balshem A. Attitudes about genetic testing for breast-ovarian cancer susceptibility. $\mathscr{f}$ Clin Oncol 1994;12:843-50.

3 Croyle RT, Lerman C. Interest in genetic testing for colon cancer susceptibility: cognitive and emotional correlates. Prev Med 1993;22:284-92.

4 Chaliki H, Loader S, Levenkron J, Logan-Young W, Hall W, Rowley P. Women's receptivity to testing for a genetic susRowley P. Women's receptivity to testing for a ge
ceptibility. Am $₹$ Public Health 1995;85:1133-5.

5 Miki Y, Swenson J, Shattuck-Eidens D, et al. A strong candidate for the breast and ovarian cancer susceptibility gene BRCA1. Science 1994;266:66-71.

6 Futreal P, Liu Q, Shattuck-Eidens D, et al. BRCA1 mutations in primary breast and ovarian carcinomas. Science 1994;266:120-2.

7 Easton DF, Ford D, Bishop T. Breast and ovarian cancer incidence in BRCAI-mutations. Am F Hum Genet 1995; 56:265-71

8 Narod SA, Ford D, Devilee P, Barkardottir RB, Lynch $H$, Smith SA. An evaluation of genetic heterogeneity in 145 breast-ovarian cancer families. Am f Hum Genet 1995; 56:254-64

9 Wooster R, Bignell G, Lancaster J, et al. Identification of the breast cancer susceptibility gene, BRCA2. Nature 1995 378:789-92.

10 Sobol H, Birnbaum D, Eisinger F. Evidence for a third breast-cancer susceptibility gene. Lancet 1994;344:1151-2.

1 Motulsky AG. Predictive genetic diagnosis. Am $\mathcal{F}$ Hum Gene 1994;55:603-5.

12 Grody WW. The coming era of cancer genetic screening. Diagn Mol Pathol 1994;3:145-6.

13 Vasen HFA. Screening in breast cancer families: is it useful? Ann Med 1994;26:185-90.

14 Gauthier J, Bouchard S. Adaptation Canadienne-Française de la forme révisée du State Trait Anxiety Inventory de Spielberger. Rev Can Sci Comport 1993;25:559-89.

15 Fuhrer R, Rouillon F. La version française de l'échelle CES-D (Center for Epidemiologic Studies-Depression Scale). Description et traduction de l'échelle d'autoévaluation. Psychiatrie Psychobiol 1989;4:163-6.

16 SAS Institute Inc, ed. SAS/STAT User's Guide, release 6.03. SAS Institute, 1988.

17 Lerman C, Seay J, Balshem A, Audrain J. Interest in genetic testing among first-degree relatives of breast cancer

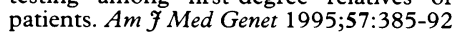

18 Skolnick MH, Cannon-Albright LA. Genetic predisposition to breast cancer. Cancer 1992;70:1747-54.

19 Andrieu N, Clavel F, Auquier A, et al Variations in the risk of breast cancer associated with a family history of breast cancer according to age at onset and reproductive factors. f Clin Epidemiol 1993;46:973-80.

20 Thompson WD. Genetic epidemiology of breast cancer. Cancer 1994;74:279-87.

21 Julian-Reynier C, Eisinger F, Chabal F, et al. Cancer genetic clinics: target population and expectations. Eur $\mathcal{f}$ Cancer 1996;32:398-403.

22 Moatti JP, Le Gales C, Julian C, Durbec J, Mattei J, Aymé S. Socio-cultural inequities in access to prenatal diagnosis: the role of insurance coverage and regulatory policies. Prenat Diagn 1990;10:313-25.

23 Struewing J, Lerman C, Kase R, Giambarresi T, Tucker M. Anticipated uptake and impact of genetic testing in hereditary breast and ovarian cancer families. Cancer Epidemiol Biomarkers and Prevention 1995;4:169-73.

24 Aymé S, Macquart-Moulin G, Julian-Reynier C, Chabal F, Giraud F. Diffusion of information about genetic risk within families. Neuromusc Disord 1993;3:571-4.

25 American Society of Human Genetics. Statement on genetic testing for breast and ovarian cancer predisposition. $A m \mathcal{F}$ Hum Genet 1994;55:1-4.

26 Hoskins KF, Stopfer JE, Calzone KA, et al. Assessment and counseling for women with a family history of breast cancer. $\mathcal{F} A M A$ 1995;27:577-85.

27 Bilimoria $M$, Morrow $M$. The woman at increased risk of breast cancer: evaluation and management strategies. Cancer $\mathcal{F}$ Clin 1995;45:263-78.

28 Michie S, McDonald V, Marteau T. Understanding responses to predictive genetic testing : a grounded theory approach. Psychol Health 1996;11:455-70.

29 McPherson K, Steel CM, Dixon J. ABC of breast diseases. Breast cancer. Epidemiology, risk factors, and genetics. BMF 1994;309:1003-6.

30 Craufurd D, Kerzin-Storrar L, Dodge A, Harris R. Uptake of presymptomatic predictive testing for Huntington's disease Lancet 1989;ii:603-6.

31 Babul R, Adam S, Kremer B, et al. Attitudes toward direct predictive testing for the Huntington disease gene. $f A M A$ 1993;270:2321-5.

32 Steenstraten MVD, Tibben A, Roos RAC, Van de Kamps JJP, Niermeijer MF. Predictive testing for huntington disease: nonparticipants compared with participants in the Dutch program. Am ₹ Hum Genet 1994;55:618-25.

33 Meissen GJ, Berchek RL. Intended use of predictive testing by those at risk for Huntington disease. Am $\mathcal{F}$ Med Genet 1987;26:283-93.

34 Kessler S, Field T, Worth L, Mosbarger H. Intended use of predictive testing by those at risk for Huntington disease. Am 7 Med Genet 1987;26:259-70.

35 Evers-Kiebooms G, Cassiman JJ, Van Den Berghe H. Attitutes towards predictive testing in Huntington's disease: tutes towards predictive testing in Huntington's disease:
recent survey in Belgium. 7 Med Genet 1987;24:275-9.

36 Evans D. Genetic testing for cancer predisposition: need and demand. F Med Genet 1995;32:161.

37 Watson M, Murday V, Lloyd S, Ponder B, Averill D, Eeles $R$. Genetic testing in breast/ovarian cancer (BRCAl) families. Lancet 1995;346:583.

\section{Appendix}

Details of the questions asked about the subjects' attitudes towards breast cancer predictive testing "We make the assumption that the average population risk of developing a cancer is between 5 and $10 \%$. Supposing it were possible to predict on the basis of a blood test whether or not you have a much higher risk than average of developing breast cancer before the age of 65 , what will your attitude be?

- Would you like to undergo this test? (yes/no/don't know)

- Will you inform the members of your family who are at risk about the availability of this test (yes/no/don't know)

Now, supposing somebody had this test and it turned out to be positive, what will this result lead to?

- Will it give the person an opportunity of monitoring her own health: better than before? the same as before? less well than before?

- Will it induce anxiety among the whole family: none? low? high? very high?

- Will it help to plan for the future: yes/no/don't know

- Will it have some drawbacks: yes, some/ yes, a lot/no/ don't know

If so, what might they be?


Supposing this test turned out to be negative:

- Will this lead to a change in the person's previous health surveillance behaviour? (yes/ no/don't know)
- Will this result help to plan for the future? (yes/no/don't know)

- Will this result have some drawbacks? (yes, some/yes a lot/no/don't know) and, if so, what might they be? 